\title{
Ultrastructural binding sites of endomysium antibodies from sera of patients with dermatitis herpetiformis and coeliac disease
}

Dermatology

Department of the

Ludwig-Maximilian

University, Munich,

Germany

S Kárpáti

M Meurer

W Stolz

O Braun-Falco

T Krieg

Department of Microbiology and Immunology, University Children's Hospital,

Basel, Switzerland

A Bürgin-Wolff

Correspondence to:

S Kárpáti, Bldg 10, R12N242, National Institutes of Health, Dermatology Branch of the National Cancer Institute, Bethesda, MD 20892 USA.

Accepted for publication 23 April 199

\author{
S Kárpáti, M Meurer, W Stolz, A Bürgin-Wolff, O Braun-Falco, T Krieg
}

\begin{abstract}
The ultrastructural binding sites of endomysium antibodies, specific serological markers of gluten sensitive enteropathy, were investigated in the rabbit oesophagus using the immunogold technique. Endomysium antibodies from sera of patients with dermatitis herpetiformis and with coeliac disease bound in an identical manner in a non-fibrillar material closely associated with fine collagenousreticulin fibrils and also with similar fibrils connecting smooth muscle cells and elastic tissue in the endomysial connective tissue. These observations suggest that IgA antibodies in sera from patients with dermatitis herpetiformis and coeliac disease recognise a common antigen in an amorphous component associated with the reticular connective tissue of oesophageal lamina muscularis mucosae and thus confirm the probable identity of IgA class endomysium and jejunal antibodies.
\end{abstract}

Sera from patients with dermatitis herpetiformis and with coeliac disease contain three types of IgA class antibodies detected by an immunofluorescence technique on human and animal tissues: antireticulin, ${ }^{12}$ antijejunal, ${ }^{34}$ and antiendomysium antibodies. ${ }^{56}$ The last two types are accepted as specific markers of gluten sensitive enteropathy. ${ }^{3-6} \mathrm{IgA}$, in contrast to IgG, antireticulin antibodies are also characteristic of coeliac disease when detected on the proper substrate. ${ }^{12}$ IgA antibodies from the sera of both types of patients which bind to normal jejunum show a similar staining pattern to that detected in the diseased jejunum of patients with gluten sensitive enteropathy. ${ }^{78}$ Therefore these antibodies were interpreted as the target organ related $\operatorname{IgA}$ class autoantibodies in coeliac disease. ${ }^{4}$

All three antibody types can be detected on both human and animal tissues. ${ }^{49}$ Recently, endomysium and antireticulin antibodies of human subtype, ${ }^{9}$ as well as endomysium and antijejunal antibodies ${ }^{4}$ were found to be identical. Previously the ultrastructural binding sites of serum IgA from dermatitis herpetiformis patients was determined on rabbit small bowel. ${ }^{10}$ To further examine possible differences between IgA class antibodies detected on different substrates, as well as between IgA class antibodies in sera from patients with dermatitis herpetiformis and coeliac disease, we carried out the first investigation to identify the target tissue constituents recognised by IgA antibodies from patients with these diseases in oesophagus at electron microscopic level using immunogold labelling.

\section{Methods}

IMMUNOFLUORESCENCE STUDIES

Serum samples taken from one coeliac and one dermatitis patient positive for endomysium antibodies in a titre 1:320, as well as serum from a patient with malabsorption syndrome without coeliac disease, were studied on rabbit and fetal human jejunum and on monkey and rabbit oesophagus as described previously. ${ }^{3}$

INDIRECT IMMUNOELECTRON MICROSCOPY (IEM) Since the most characteristic feature of endomysium antibodies is a honeycomb like fluorescence along the lamina muscularis mucosae, we studied this part of the oesophagus, as described previously..$^{10}$ Briefly, small pieces of tissue were fixed for two hours at room temperature in $4 \%$ paraformaldehyde and $0.1 \%$ glutaraldehyde in phosphate buffer $(0.1 \mathrm{~mol} / \mathrm{l}$, $\mathrm{pH} 7 \cdot 2$ ) and were cut into $0 \cdot 5-1 \mathrm{~mm}$ strips, rinsed in graded series of $10-20-30 \%$ sucrose$\mathrm{NaCl}(0.9 \%)$ solution, and quick frozen in liquid nitrogen. The samples were then incubated for 48 hours at $4^{\circ} \mathrm{C}$ with endomysium antibody positive and negative sera diluted 1:20 in phos-

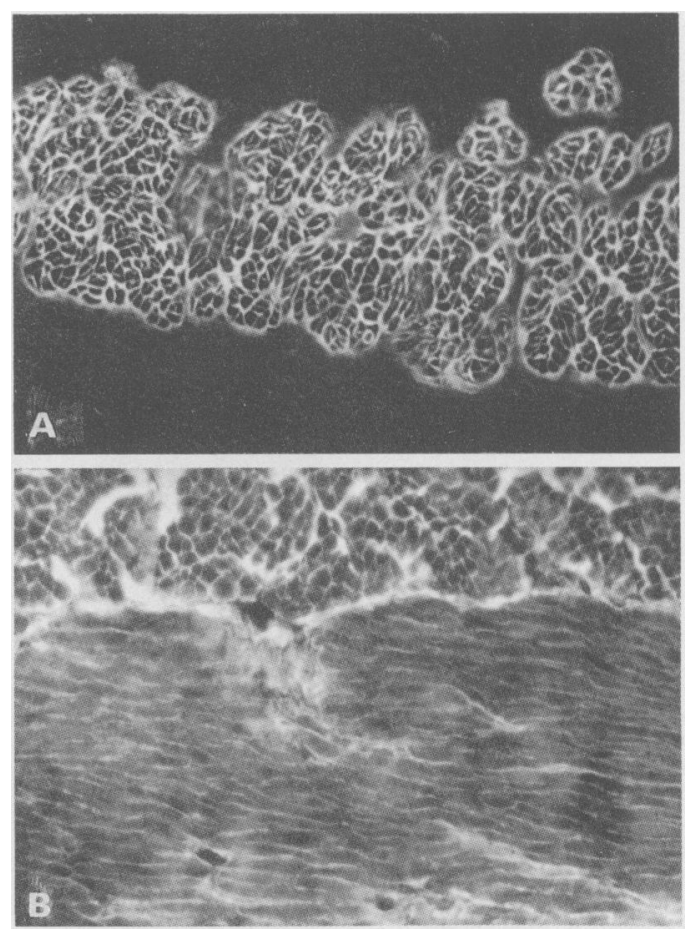

Figure 1: Indirect immunofluorescence: binding of IgA from sera of dermatitis herpetiformis $(A)$ and coelic $(B)$ patients along the endomysium of oesophageal $(A)$ and intestinal $(B)$ smooth muscle layers. Note the similar honeycomb like fluroescence. (Original magnification: $A \times I 20, B \times 180$.) 
Figure 2: Electron micrographs showing rabbit oesophagus stained by endomysium antibodies from serum of a patient with coeliac disease. Immunogold labelling: note gold deposition in a non-fibrillar component next to $(A)$ fine collagenous-reticulin fibrils in the endomysial connective tissue of lamina muscularis; $(B)$ fine collagenous-reticulin fibrils connecting the basement membranes of neighbouring smooth muscle cells.

(Original magnification: $A \times 29000$, inset $\times 120000$, $B \times 82900$, inset $\times 140000$.)

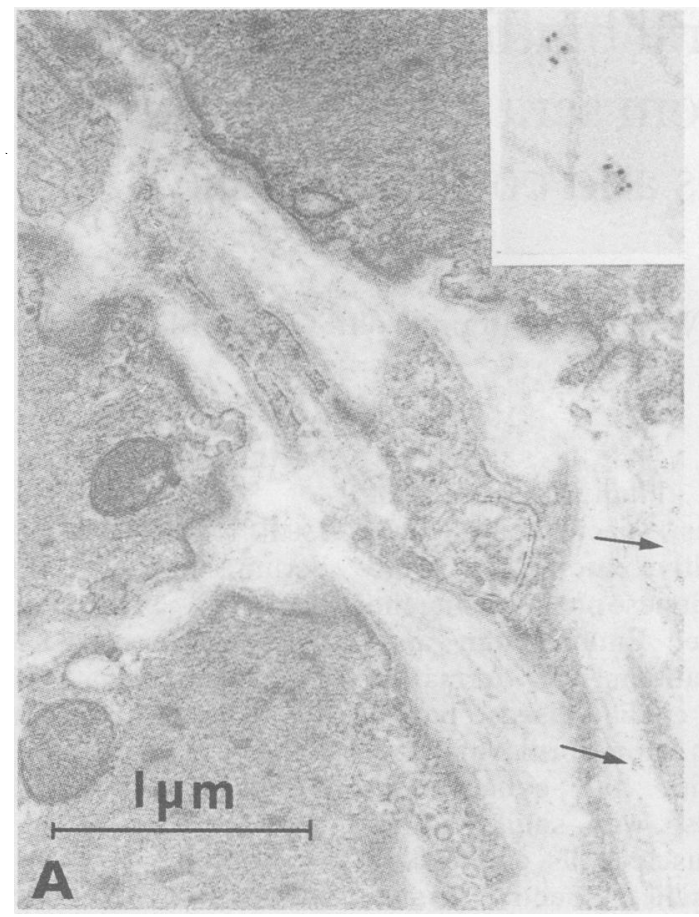

phate buffered saline $(0.01 \mathrm{~mol} / \mathrm{l}, \mathrm{PH}: 7 \cdot 4)$, with mouse monoclonal antibody to human IgA (Zymed Laboratories, USA) (diluted 1:10 in phosphate buffered saline) and with $5 \mathrm{~nm}$ gold-conjugated goat antimouse serum (Janssen Life Sciences, Belgium), diluted 1:15 in Tris$\mathrm{HCl}$ buffer (Tris $20 \mathrm{mmol} / \mathrm{l}, \mathrm{NaN}_{3} 20 \mathrm{mmol} / \mathrm{l}$, $\mathrm{pH} 7 \cdot 6)$ at room temperature for two hours. The tissue was postfixed in Karnovsky and $1 \% \mathrm{OsO}_{4}$ solutions and embedded in epoxy resin (Epon 812) (Serva, Germany).

\section{Results}

IMMUNOFLUORESCENCE STUDIES (FIG I) Sera from both dermatitis herpetiformis and

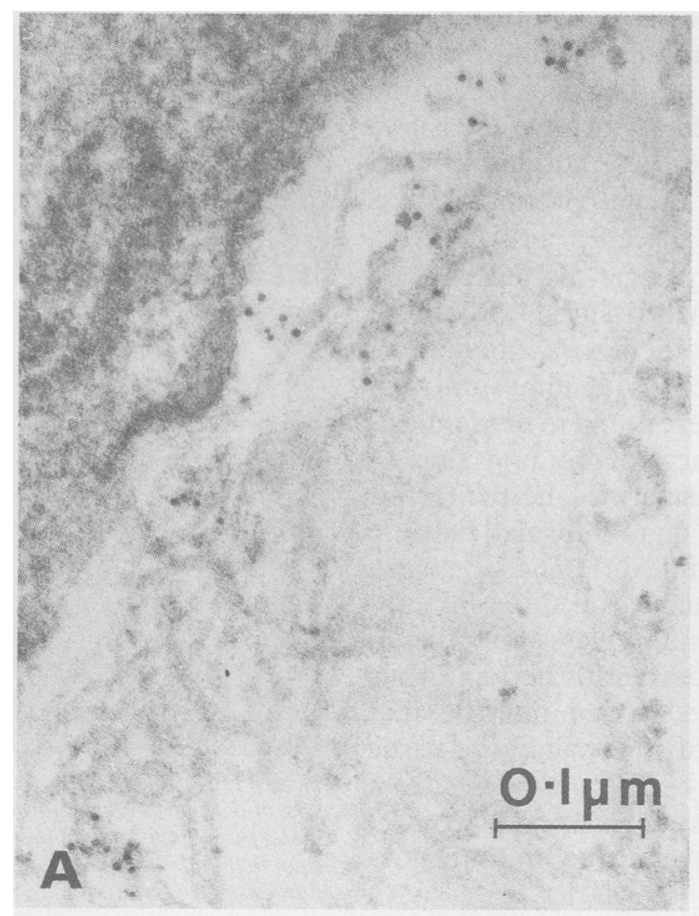

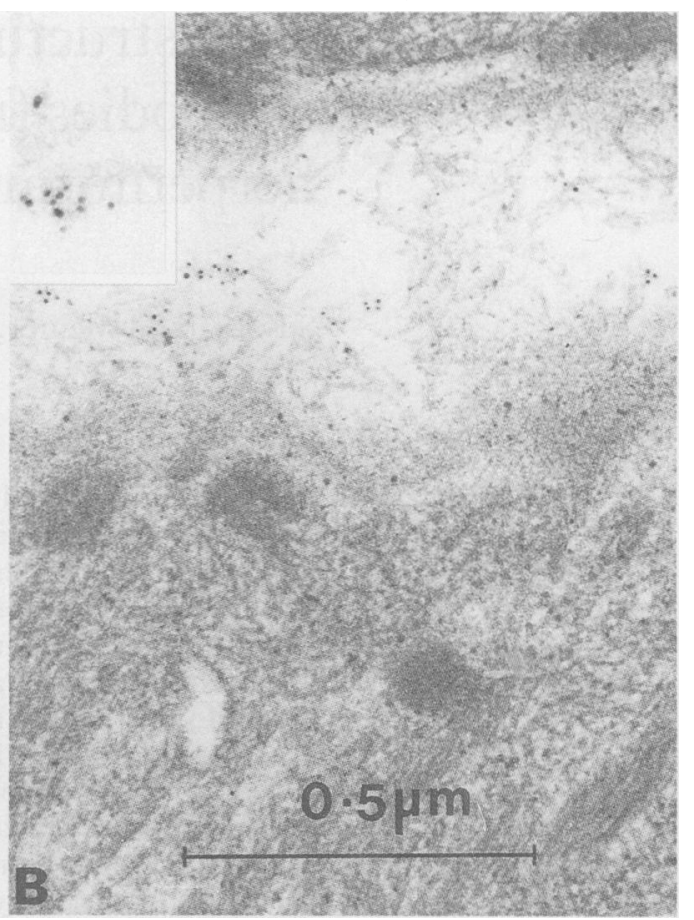

coeliac patients produced an identical honeycomb like fluroescence along the endomysium of oesophageal (Fig 1A) and jejunal (Fig 1B) smooth muscle layers in titre of 1:160-1:320. No fluorescence was detected when control serum was studied.

\section{ULTRASTRUCTURAL DETERMINATION OF}

ENDOMYSIUM ANTIBODY BINDING SITES USING IMMUNOGOLD LABELLING (FIGS 2-4)

Both studies with coeliac serum (Fig 2) and dermatitis herpetiformis serum (Fig 3 ) resulted in similar staining patterns on rabbit oesophagus. Endomysium antibody binding was detected in the endomysial connective tissue between the smooth muscle bands (Fig 2A) as well as between the smooth muscle cells (Fig 2B). Gold particles

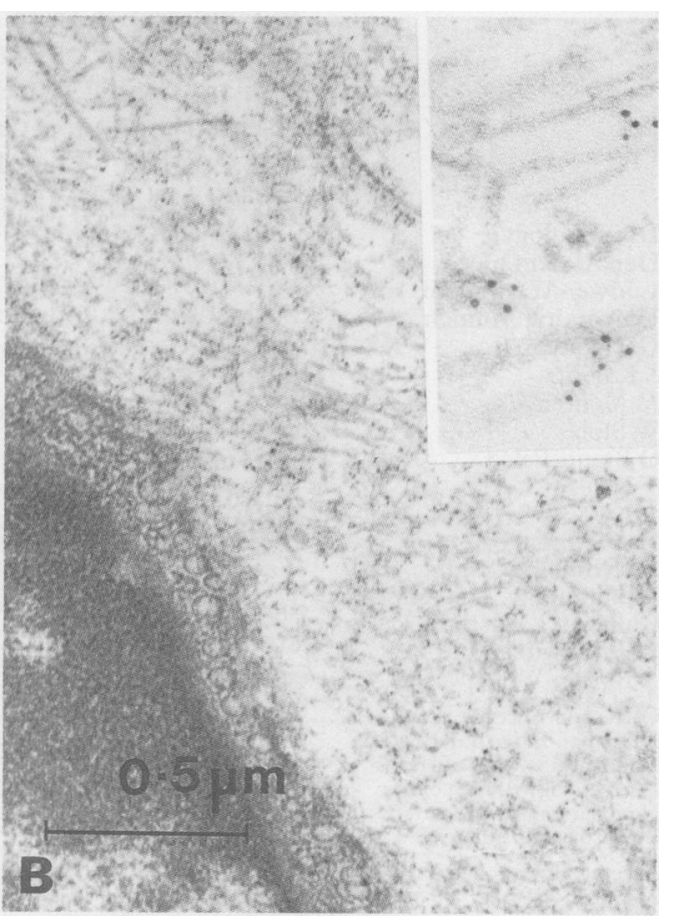

Figure 3: Ultrastructural binding of IgA from dermatitis herpetiformis serum to rabbit oesophageal smooth muscle layer. Note gold particles in amorphous material along fine

collagenous-reticulin fibrils $(B)$ and $(A)$ along fibrils adjacent endomysial elastic tissue. (Original magnification $A \times 40700$ inset $\times 156000, B$ $\times 173000$.) 
Figure 4: Control experiment on rabbit oesophagus with serum without endomysium antibodies. (Original magnification $\times 95000$.)

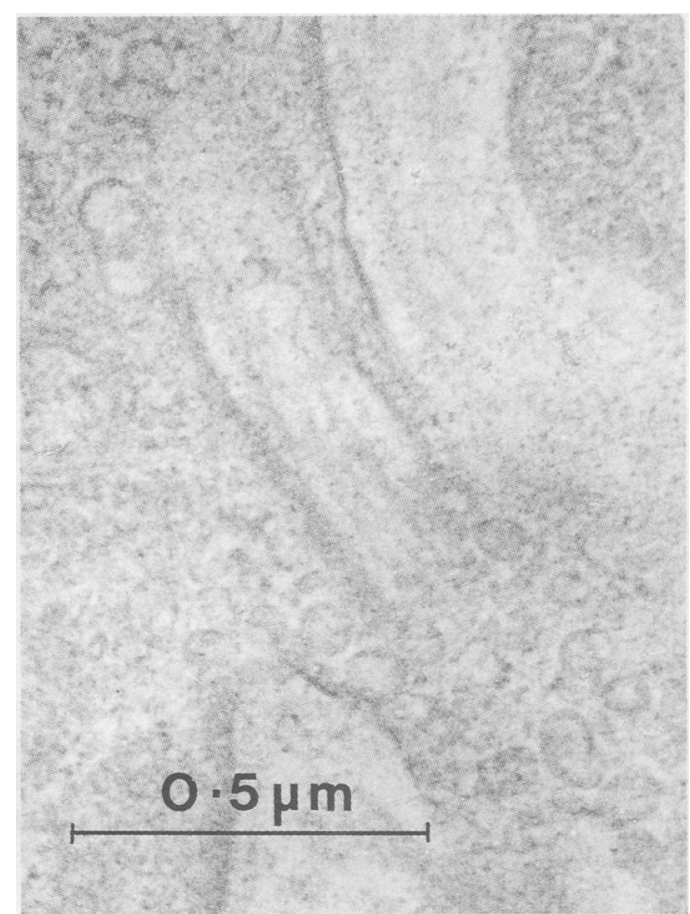

were deposited in amorphous material adjacent to fine collagenous-reticulin fibres of different diameters (Fig 2, 3B), connecting the basement membranes of neighbouring smooth muscle cells (Fig 2B), or adjacent marginal smooth muscle cells (Fig 3B). Between the smooth muscle cells and in the marginal perimysial connective tissue, elements of elastic tissue were also recognised. In these regions similar fine fibrils were detected between smooth muscle cells and elastic tissue. Here, too, gold particles were seen in a nonfibrillar material adjacent to the fine fibrils (Fig 3A). Control experiments with endomysium antibody negative serum did not show specific gold depositions (Fig 4).

\section{Discussion}

Indirect immunoelectron microscopy of rabbit oesophagus using endomysium antibody positive sera from patients with dermatitis herpetiformis and coeliac disease showed identical IgA antibody binding in an amorphous component adjacent to fine collagenous-reticulin fibrils of the endomysial connective tissue. These fibrils connected neighbouring smooth muscle cells, smooth muscle bands, and elastic tissue and smooth muscle cells.

In previous ultrastructural studies in rabbit jejunum with antijejunam antibody positive dermatitis herpetiformis serum, IgA antibodies also recognised amorphous material adjacent to collagenous-reticulin fibres underlying the basement membrane, around capillaries, between smooth muscle cells, and between smooth muscle cells and elastic tissue in jejunal vessel walls. ${ }^{10}$ Our recent experiences with antijejunal and endomysium antibodies suggest that these antibodies could be identical. ${ }^{+}$

On the basis of ultrastructural staining characteristics, both endomysium and antijejunal antibodies are supposed to be an IgA antireticulin antibody. In recent absorption studies Hallström could not distinguish IgA class antireticulin antibodies. In recent absorption studies from endomysium antibodies reacting with monkey oesophagus. ${ }^{9}$

The biochemical composition of endomysium, similar to that of reticulin, is not precisely defined, and may correspond to a group of different fibrillar and amorphous components: collagen I and III fibres, elastic tissue, fibronectin, non-collagenous proteins, and proteoglycans. ${ }^{11-13}$ Both endomysium and reticulin are argyrophilic and strongly periodic acid-Schiff reactive, probably because of the high proteoglycan content of the interfibrillar matrix. According to our observations, some of these interfibrillar components may represent the antigen recognised in patients with dermatitis herpetiformis and coeliac disease.

The results of the present immunoelectron microscopic study further corroborate the probable identity of endomysium and jejunal antibodies and show that sera of patients with dermatitis herpetiformis and coeliac disease react with an identical tissue component present in different animal and human tissues.

Supported by the Humboldt Foundation, Bonn, Germany

1 Mäki M, Hällström O, Vesikari T, Visakorpi JK. Evaluation of a serum IgA-class reticulin antibody test for the detection of childhood celiac disease. $\mathcal{F}$ Pediatr 1984; 105: $901-5$.

2 Hällström $O$, Reunala T. IgA class reticulin antibodies in dermatitis herpetiformis: a good indicator of jejunal damage. Acta Derm Venereol (Stockh) 1985; 65: 330-65.

3 Kárpáti S, Török E, Kosnai I. IgA class antibody against human jejunum in sera of children with dermatitis herpetiformis. F Invest Dermatol 1986; 87: 703-6.

4 Kárpáti S, Bürgin-Wolff A, Krieg T, Meurer M, Stolz W, Braun-Falco O. Binding to human jejunum of serum IgA antibody from children with coeliac disease. Lancet 1990; 336: $1335-8$

5 Chorzelski TP, Beutner EH, Sulej J, Tchorzewska H, Jablonska S, Kumar V, et al. IgA Antiendomysial antibody. A new serological marker of dermatitis herpetiformis and coeliac disease. Br f Dermatol 1984; III: 395-402.

6 Bürgin-Wolff A, Gaze H, Hadziselimovic F, Lentze $M J$, Nussle D. The diagnostic significance of gliadin and endomysium antibodies in childhood coeliac disease. In: Bürginmysium antibodies in childhood coeliac disease. In: BürginWolff A, Hadziselimovic F, Herzog B, eds Inflammatory
bowel disease and coeliac disease in children. London: Kluwer bowel disease and coeliac dise

7 Shiner M, Ballard J. Antigen-antibody reactions in jejunal mucosa in childhood coeliac disease after gluten challenge. Lancet 1972; i: 1202-5.

8 Kárpáti S, Kosnai I, Török E, Kovács JB. Immunoglobulin A deposition in jejunal mucosa of children with dermatitis herpetiformis. F Invest Dermatol 1988; 91: 336-9.

9 Hällström $\mathrm{O}$. Comparison of IgA-clas reticulin and endomysium antibodies in coeliac disease and dermatitis herpetiformis. Gut 1989; 30: 1225-32.

10 Kárpáti S, Stolz W, Meurer M, Krieg T, Braun-Falco $O$. Extracellular binding sites of anti-jejunal antibodies on normal small bowel using indirect immunoelectron microscopy. F Invest Dermatol 1991; 96: 228-33.

11 Ferraz de Carvalho CA, König B Jr. Light and electron microscopic study on the oxytalan, elaunin and elastic fibres in the inferior segment of the human esophagus. Anat Anz

12 Lehto $M$, Kvist $M$, Vieno T, Jozsa L. Macromolecular composition of the sarcolemma and endomysium in the rat. Acta Anat 1988; 133: 297-302.

13 Velician C, Velician D. Studies on the reticulin network of human liver. Virchows Arch [B] 1968; 1: 297-316. 